\title{
INVESTIGATION OF PEM FUEL CELL FOR AUTOMOTIVE USE
}

\author{
A.K.M. Mohiuddin, Ataur Rahman, Mohamed FadHIL Chemani ANd \\ MOHD BAIHAQI ZAKARIA \\ Department of Mechanical Engineering, Faculty of Engineering, \\ International Islamic University Malaysia, \\ Jalan Gombak, 53100, Kuala Lumpur, Malaysia \\ mohiuddin@iium.edu.my,arat@iium.edu.my,cbr1000_fadhil@yahoo.com,and \\ scuderia889@gmail.com
}

(Received: Oct. 30, 2015; Accepted: Nov.10, 2015; Published on-line: Nov. 30, 2015)

\begin{abstract}
This paper provides a brief investigation on suitability of Proton-exchange membrane fuel cells (PEMFCs) as the source of power for transportation purposes. Hydrogen is an attractive alternative transportation fuel. It is the least polluting fuel that can be used in an internal combustion engine (ICE) and it is widely available. If hydrogen is used in a fuel cell which converts the chemical energy of hydrogen into electricity, (NOx) emissions are eliminated. The investigation was carried out on a fuel cell car model by implementing polymer electrolyte membrane (PEM) types of fuel cell as the source of power to propel the prototype car. This PEMFC has capability to propel the electric motor by converting chemical energy stored in hydrogen gas into useful electrical energy. PEM fuel cell alone is used as the power source for the electric motor without the aid of any other power source such as battery associated with it. Experimental investigations were carried out to investigate the characteristics of fuel cell used and the performance of the fuel cell car. Investigated papameters are the power it develops, voltage, current and speed it produces under different load conditions.
\end{abstract}

ABSTRAK: Kertas kerja ini memberikan penyelidikan ringkas tentang keserasian penukaran membran sel bahan api Proton (PEMFCs) sebagai punca kuasa untuk tujuan pengangkutan. Hidrogen merupakan bahan api pengangkutan alternatif yang menarik. Ia merupakan sumber bahan api yang banyak dan paling kurang mencemar yang boleh digunakan sebagai engin pembakaran dalaman (ICE). Penggunaan hidrogen dalam sel bahan api dapat menukarkan tenaga kimia hidrogen kepada elektrik, di mana pengeluaran (NOx) dapat disingirkan. Penyelidikan dijalankan ke atas model kereta sel bahan api dengan menggunakan jenis sel bahan api membran elektrolik berpolimer (PEM) sebagai sumber tenaga untuk menjanakan kereta prototaip. Penggunaan PEMFC membolehkan penjanaan kuasa elektrik motor dengan menukarkan tenaga kimia yang terkandung dalam gas hidrogen sebagai tenaga elektrik yang berguna. Sel bahan api PEM secara sendirinya digunakan sebagai sumber tenaga kepada motor elektrik tanpa bantuan daripada sumber tenaga lain seperti bateri. Penyelidikan eksperimental dijalankan untuk mengkaji sifat sel bahan api yang digunakan dan keupayaan sel bahan api kereta. Parameter yang dikaji termasuklah tenaga yang dihasilkan, voltan, arus dan kelajuan yang terhasil daripada bebanan yang berbeza.

KEYWORDS: fuel cell; automotive; proton exchange membrane; polymer electrolyte membrane; internal combustion engine 


\section{INTRODUCTION}

Motor vehicles account for $30 \%$ to $70 \%$ of emissions of all urban air pollutants (EPA, 1991) [1], and up to $30 \%$ of emissions of carbon dioxide from the use of petroleum fuels [2]. In most countries of the world, ground transportation exclusively uses petroleum fuels. The vulnerable supply and price volatility in the world oil market have motivated researchers and policy makers to seek alternatives to gasoline and diesel fuel.

Hydrogen is an attractive alternative transportation fuel. It is the least polluting fuel that can be used in an internal combustion engine (ICE) and it is available anywhere where water is available and is a clean source of power. The prospect of a clean, widely available transportation fuel has prompted much of the research on hydrogen fuels. Hydrogen has been successfully demonstrated in experimental cars, buses and trucks [3-5]. If hydrogen is used in an internal combustion engine (ICE), the only pollutant of concern is oxides of nitrogen $\left(\mathrm{NO}_{\mathrm{x}}\right)$, which can be controlled to low levels. But if hydrogen is used in a fuel cell which converts the chemical energy of hydrogen into electricity, (NOx) emissions are eliminated.

A fuel is a device that converts chemical energy to direct current electrical energy. PEM fuel cells use a proton conductive polymer membrane as electrolyte. PEM stands for Polymer Electrolyte Membrane or Proton Exchange Membrane. Sometimes they are also called polymer membrane fuel cells, or just membrane fuel cells. In the early days (1960s) they were known as Solid Polymer Electrolyte (SPE) fuel cells. This technology has drawn the most attention because of its simplicity, viability, quick start-up, and it has been demonstrated in almost any conceivable application, from powering a cell phone to a locomotive [6]. By converting an on-board fuel to electricity it could be effectively used to power an electric vehicle. As such, a fuel cell is an energy conversion device like an internal combustion engine. The objective of this work is to investigate the suitability of PEMFC for automotive use through a fuel cell car prototype which will be powered by PEM fuel cell.

Proton-exchange membrane fuel cells (PEMFCs) are considered to be a promising technology for efficient power generation in the $21^{\text {st }}$ century. PEMFCs are one of the most promising clean energy technologies. PEMFCs have certain potential advantages, such as portable applications, power generation, high efficiency, etc. [7, 8]. The key constituent of a PEMFC is a dense proton-exchange membrane, which is responsible for proton migration from the anode to the cathode. Hydrogen is catalytically oxidized in the anode to produce protons. The membrane is generally placed between two electrodes, i.e. between the anode and cathode. The protons thus produced can migrate from the anode to cathode where the protons react with oxygen to produce water and heat [9]. Over the past few years, there have been intense efforts worldwide to develop low-cost PEMFC systems.

\section{FUEL CELL}

Fuel cells are electrochemical devices that process hydrogen and oxygen to generate electric power, and water vapor comes out as their only by-product. Figure 1 shows the basic operation of a fuel cell. Hydrogen is channeled through fuel flow plates to the anode on one side of the fuel cell, while oxygen on the other side of the cell. At the anode, a platinum catalyst causes the hydrogen to split into positive hydrogen ions (protons) and negatively charged (electrons). The polymer electrolyte membrane (PEM) allows only positively charged ions to pass through it to the cathode. The negatively charged electrons must travel along external circuit (load) to the cathode, creating an electrical current. At 
the cathode, the electrons and positively charged hydrogen ions combine with oxygen to form water, which flows out of the cell [10].

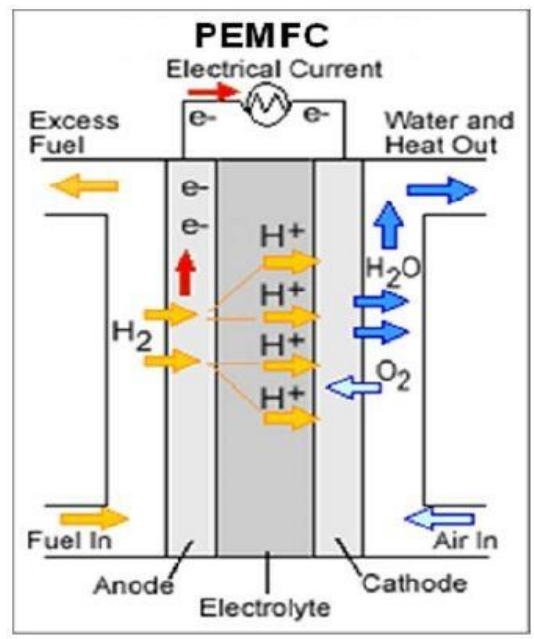

Fig. 1: Fuel cell basic operation.

There are four basic components in a single cell of PEMFC and they are:

- Anode: It is the negative side of the fuel cell. It conducts the electrons that are freed from the hydrogen molecules and are used in an external circuit. Channels etched into the anode disperse the hydrogen gas equally over the surface of the catalyst.

- Cathode: It is the positive side of the fuel cell and also contains channels that distribute the oxygen to the surface of the catalyst. It conducts the electrons back from the external circuit to the catalyst, where they can recombine with the hydrogen ions and oxygen to form water.

- Polymer electrolyte membrane: PEM is a specially treated material that looks something like ordinary kitchen plastic wrap, only conducts positively charged ions and blocks the electrons. The PEM is the key to the fuel cell technology. It must permit only the necessary ions to pass between the anode and cathode. Other substances passing through the electrolyte would disrupt the chemical reaction.

- Catalyst: All electrochemical reactions in a fuel cell consist of two separate reactions, an oxidation half-reaction at the anode and a reduction half-reaction at the cathode. Usually, the two half-reactions would occur very slowly at the low operating temperature of the PEM fuel cell. Each of the electrodes is coated on one side with a catalyst layer that speeds up the reaction of oxygen and hydrogen. It is usually made of platinum powder, very thinly coated onto carbon paper or cloth. The catalyst is rough and porous so that the maximum surface area of the platinum can be exposed to the hydrogen or oxygen.

The voltage resulting from the reaction of the fuel (hydrogen) and oxygen varies with the load. Due to their low output voltage it becomes necessary to stack many cells in series to realize a practical system. For low power applications, the number of cells that needs to be connected in series is small, but as power increases the number of cells that are required in the stack increases rapidly. For example, to produce $100 \mathrm{~V}$ fuel cell, the stack consists of 250 cells in series and to produce $300 \mathrm{~V}$ at full load, the fuel cell stack requires 750 cells in series. 


\subsection{Types of Fuel Cells}

There are many types of fuel cells that are currently being researched to make them commercially viable. Some of them are polymer electrolyte membrane fuel cells (PEMFCs), alkaline fuel cell (AFCs), phosphoric acid fuel cell (PAFCs), solid oxide fuel cell (SOFCs), and molten carbonate fuel cells (MCFCs). A brief comparison of these fuel cells is given in Table 1 [11].

Table 1: Comparison of fuel cell technology.

\begin{tabular}{|c|c|c|c|c|c|}
\hline $\begin{array}{l}\text { Fuel Cell } \\
\text { Type }\end{array}$ & $\begin{array}{l}\text { Polymer } \\
\text { Electrolyte } \\
\text { Membrane } \\
\text { (PEMFC) }\end{array}$ & $\begin{array}{l}\text { Alkaline } \\
\text { (AFC) }\end{array}$ & $\begin{array}{l}\text { Phosphoric } \\
\text { Acid } \\
\text { (PAFC) }\end{array}$ & $\begin{array}{l}\text { Molten } \\
\text { Carbonate } \\
\text { (MCFC) }\end{array}$ & $\begin{array}{l}\text { Solid Oxide } \\
\text { (SOFC) }\end{array}$ \\
\hline Fuel & $\mathrm{H}_{2}$ & $\mathrm{H}_{2}$ & $\mathrm{H}_{2}$ & $\mathrm{H}_{2} / \mathrm{CO} /$ reformate & $\mathrm{CO}, \mathrm{H}_{2}$ \\
\hline Oxidizer & $\mathrm{O}_{2}$, air & $\mathrm{O}_{2}$, air & $\mathrm{O}_{2}$, air & $\mathrm{CO}_{2}, \mathrm{O}_{2}$, air & $\mathrm{O}_{2}$, air \\
\hline $\begin{array}{l}\text { Common } \\
\text { Electrolyte }\end{array}$ & $\begin{array}{l}\text { Hydrated } \\
\text { Polymeric Ion } \\
\text { Exchange } \\
\text { Membranes }\end{array}$ & $\begin{array}{l}\text { Mobilized or } \\
\text { Immobilized } \\
\text { Potassium } \\
\text { Hydroxide in } \\
\text { asbestos } \\
\text { matrix }\end{array}$ & $\begin{array}{l}\text { Immobilized } \\
\text { Liquid } \\
\text { Phosphoric } \\
\text { Acid in SiC }\end{array}$ & $\begin{array}{l}\text { Immobilized } \\
\text { Liquid } \\
\text { Molten } \\
\text { Carbonate in } \\
\mathrm{LiAlO}_{2}\end{array}$ & $\begin{array}{l}\text { Perovskites } \\
\text { (Ceramics) }\end{array}$ \\
\hline $\begin{array}{l}\text { Operating } \\
\text { Temperature }\end{array}$ & $40-80{ }^{\circ} \mathrm{C}$ & $65-220^{\circ} \mathrm{C}$ & $205^{\circ} \mathrm{C}$ & $650^{\circ} \mathrm{C}$ & $600-1000^{\circ} \mathrm{C}$ \\
\hline $\begin{array}{l}\text { Typical } \\
\text { Stack Size }\end{array}$ & $1 \mathrm{~kW}-250 \mathrm{~kW}$ & $10-100 \mathrm{~kW}$ & $400 \mathrm{~W}$ & $300 \mathrm{~kW}-3 \mathrm{MW}$ & $1 \mathrm{~kW}-2 \mathrm{MW}$ \\
\hline Efficiency & $\begin{array}{l}60 \% \\
\text { (Transportation) } \\
35 \% \\
\text { (Stationary) }\end{array}$ & $60 \%$ & $40 \%$ & $50-60 \%$ & $50-60 \%$ \\
\hline Applications & $\begin{array}{l}\text {-Backup power } \\
\text {-Portable power } \\
\text {-Distributed } \\
\text { generation } \\
\text {-Transportation } \\
\text {-Specialty } \\
\text { vehicle }\end{array}$ & $\begin{array}{l}\text {-Military } \\
\text {-Space }\end{array}$ & $\begin{array}{l}\text { Distributed } \\
\text { generation }\end{array}$ & $\begin{array}{l}\text {-Electric utility } \\
\text {-Distributed } \\
\text { generation }\end{array}$ & $\begin{array}{l}\text {-Auxiliary power } \\
\text {-Electric utility } \\
\text {-Distributed } \\
\text { generation }\end{array}$ \\
\hline Advantages & $\begin{array}{l}\text {-Solid } \\
\text { electrolyte } \\
\text { reduce } \\
\text { corrosion \& } \\
\text { electrolyte } \\
\text { management } \\
\text { problems } \\
\text {-Low } \\
\text { temperature } \\
\text {-Quick start-up }\end{array}$ & $\begin{array}{l}\text {-Cathode } \\
\text { reaction } \\
\text { faster in } \\
\text { alkaline } \\
\text { electrolyte, } \\
\text { leads to high } \\
\text { performance } \\
\text {-Low cost } \\
\text { component }\end{array}$ & $\begin{array}{l}\text {-High } \\
\text { temperature } \\
\text { enable } \\
\text {-Increase } \\
\text { tolerance to } \\
\text { full impurities }\end{array}$ & $\begin{array}{l}\text {-High efficiency } \\
\text {-Fuel flexibility } \\
\text {-Can use variety } \\
\text { of catalyst } \\
\text {-Suitable for } \\
\text { CHP }\end{array}$ & $\begin{array}{l}\text {-High efficiency } \\
\text {-Fuel flexibility } \\
\text {-Can use variety } \\
\text { of catalyst } \\
\text {-Solid electrolyte } \\
\text {-Suitable for } \\
\text { CHP\&CHHP } \\
\text {-Hybrid/GT } \\
\text { cycle }\end{array}$ \\
\hline Challenges & $\begin{array}{l}\text {-Expensive } \\
\text { catalyst } \\
\text {-Sensitive to } \\
\text { fuel impurities }\end{array}$ & $\begin{array}{l}\text { Electrolyte } \\
\text { management }\end{array}$ & $\begin{array}{l}\text {-Pt catalyst } \\
\text {-Long start } \\
\text { up time }\end{array}$ & $\begin{array}{l}\text {-High } \\
\text { temperature } \\
\text { corrosion and } \\
\text { breakdown of } \\
\text { cell components } \\
\text {-Long start up } \\
\text { time } \\
\text {-Low power } \\
\text { density }\end{array}$ & $\begin{array}{l}\text { High } \\
\text { temperature } \\
\text { corrosion and } \\
\text { breakdown of } \\
\text { cell components }\end{array}$ \\
\hline
\end{tabular}




\subsection{Transportation Applications}

Fuel cells could be used for many transportation applications, such as automobiles, buses, utility vehicles and scooters and bicycles. Most automobile manufacturers have been developing fuel cell vehicles for at least a decade, and have demonstrated at least one prototype vehicle. The major reasons for developing automotive fuel cell technology are their efficiency, low or zero emissions, and fuel that could be reproduced from local sources rather than imported. Some automobile manufacturers such as General Motors, Toyota, and Honda are working on their own fuel cell technology. Other automobile manufacturers such as Ford, Mazda, DaimlerChrysler, Mazda, Hyundai, Fiat, and Volkswagen buy their fuel cells from fuel cell manufacturing companies. The types of fuel cells commonly used are the PEMFC and the Direct Methanol Fuel Cell (DMFC).

Automotive fuel cells can have one or all of the following characteristics [11]:

i) A fuel cell is sized to provide all of the power to a vehicle. A battery may be present for startup.

ii) A fuel cell typically supplies a constant amount of power, so for vehicle acceleration and other power spikes, additional devices are typically switched on such as batteries, ultra or supercapacitors, and so on.

iii) Sometimes a fuel cell is used as the secondary power source. A system is set up where batteries power the vehicle, and the fuel cell just recharges the batteries when needed.

iv) A fuel cell can run part or all of the vehicles electrical system. Sometimes another engine is used for propulsion.

\subsection{Fuel Cells Selection for Automotive Application}

Detailed study of different fuel cells characteristics helped us to select the correct type of fuel cell [12]. PEMFC fuel cell shows the best characteristic to use in vehicle application [13]. The most important factors that make PEMFC become the chosen fuel cell to be used in the prototype are [6]:

a) High chemical stability: It is important in PEM as the membrane plays the key role. If the polymer degrades, this will reduce the energy output of the fuel cell. If the membrane breaks, there will then be a path for the oxidant and the fuel to react directly.

b) High proton conductivity: In the fuel cell, hydrogen ions must be able to easily reach the cathode and complete the electrochemical circuit. Further, resistance (Ohmic) polarization is a major contribution to voltage loss in the typical range of operating current densities. Most of this resistance is due to resistance to ion flow in the membrane. The conductivity of a membrane is a function of the water content as well as the ion exchange capacity.

c) Low cost: Apart from bi-polar plate material costs, Nafion ${ }^{\mathrm{TM}}$ cost reduction is a major requirement of PEMFC market penetration. It has been estimated that Nafion ${ }^{\mathrm{TM}}$ will make up as much as 18 percent of the total cost of the cell. Thus a lower cost material is desirable.

d) Thermal Stability: It is referred to have a polymer membrane that is stable at higher temperature. If the polymer does not degrade at higher temperatures it will then become possible to operate the fuel cell at higher temperatures. Currently PEMFCs operate at $80{ }^{\circ} \mathrm{C}$. At higher temperatures Nafion ${ }^{\mathrm{TM}}$ becomes dehydrated and conductivity drops. A higher temperature would aid the kinetics of the cathode 
reaction (which are current limiting), as well as reduce carbon monoxide poisoning of the anode catalyst.

e) Durability: Apart from chemical and thermal stability, the membrane must be durable. A very strong material can allow for thinner membranes to be developed, which improve ion conductivity. More durable materials will also last longer. A criterion presented by reference sets the durability at 10 years for the PEM. A separate durability criterion by the USDOE looks for durability of $5000 \mathrm{~h}$ for a 50 $\mathrm{kW}$ system used in a car.

f) Low expansion: With water uptake there is an inevitable expansion of the membrane. Too much expansion of the membrane creates pressure on the bi-polar plates (which may consequently crack), and the plate may also buckle off which is detrimental for the fuel cell.

\section{MODEL CAR FOR INVESTIGATION}

In this project we have assembled a fuel cell car prototype by implementing PEM type of fuel cell as source of power to propel the prototype car. It has the capability to propel the electric motor by performing chemical reaction and converting chemical energy stored in hydrogen gas into useful electrical energy. In this fuel cell car prototype, PEMFC alone is used as the power source to run the electric motor without any other power source [12].

\subsection{Prototype Selection}

The first step in developing the product was determining the type of the car. In this case, a remote control (RC) car model was chosen as the product. Its movement can be controlled freely. There are different components in a RC car. The components are: chassis, suspension, drive train, tires, engine/motor, bearings, etc.

\subsection{Electric Motor Selection}

Electric motor acts as an engine of the car substituting the internal combustion engine. There are several types of motors available in the market. To select the best suited motor for a RC car, it is essential to know the size of the model and amount of cells planned to be used. Size of the RC vehicle will determine the size of motor needed to push the weight. For motors this is often best represented by the amount of weight of the motor itself. In this project, RS-540SH-6527 motor of capacity range 7-9 volt was chosen since it can propel the car with high speed and also can carry a load up to $4 \mathrm{~kg}$.

\subsection{Fuel Cell Stack Selection}

H-30 FCS-B30 PEM fuel cell is selected to power the car model for its earlier mentioned advantages. Range of voltage it produces must be equal or lower than that of the electric motor chosen to make the motor works in optimum performance and also to avoid overheating. If the voltage produced by fuel cell is lower than that needed by the motor, the motor will run slowly and not uniformly. This PEM fuel cell can only stand for 0.5 bars. But hydrogen tank storage supplies the hydrogen at a pressure up to 10 bar. So to reduce this high pressure from hydrogen storage tank, a pressure regulator is used.

\subsection{Hydrogen Storage Tank Selection}

In the development of fuel cell vehicles, hydrogen storage is the biggest remaining research problem according to the Office of Science and Technology Policy, Executive Office of the US President (January 2003). Current hydrogen storage systems are inadequate to meet the needs of consumers in a fuel cell vehicle. Existing and proposed technologies for hydrogen storage include (1) physical storage: pressurized tanks for gaseous hydrogen and pressurized cryo-tanks for liquid hydrogen; (2) reversible hydrogen 
uptake in various metal-based compounds including hydrides, nitrides, and imides; (3) chemical storage in irreversible hydrogen carriers such as methanol; (4) cryo-adsorption with activated carbon as the most common adsorbent; and (5) advanced carbon materials absorption, including carbon nanotubes, alkali-doped carbon nanotubes, and graphite nanofibers.

In this project, metal hydride hydrogen storage tank is used which is manufactured by Horizon company called as HYDROSTIKTM. Metal hydride tank is a container loaded with hydrogen storage alloy powder, heat exchange parts, and gas transport components. The container body materials are generally aluminum alloy or stainless steel. Hydrogen being stored at low pressure in the vessel, they provide a safe and reliable energy storage, particularly for portable applications, in-house and on-board storage. The weight is also low just $90 \mathrm{~g}$ and can store about $10 \mathrm{~L}$ compressed hydrogen gas.

\section{FUEL CELL CAR ASSEMBLY}

Figure 2 shows the model assembly based on material selection as mentioned above.

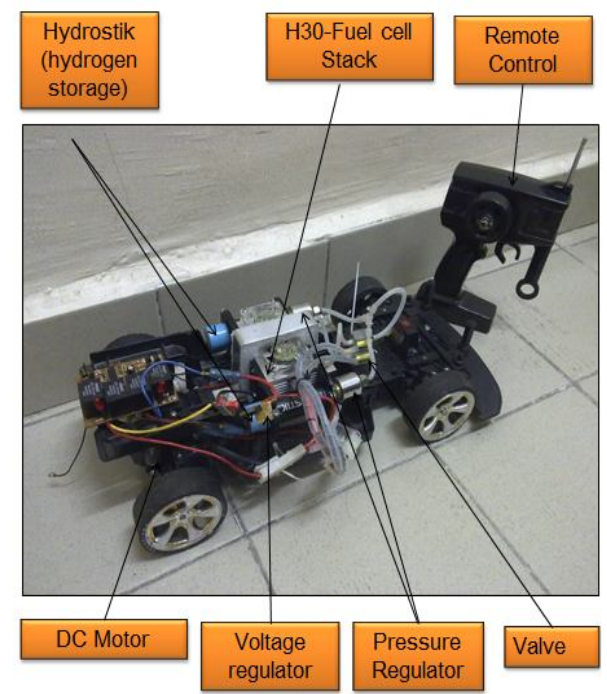

Fig. 2: Final product, PEM fuel cell car prototype.

\section{RESULTS AND DISCUSSION}

\subsection{Experiment on PEMFC Performance}

Experiments were carried out to detemine the performance of H30 PEMFC. It was allowed to reach its maximum output before it was added to the fuel cell car prototype. Besides that, the flowrate of hydrogen was measured to determine its consumption. Progrmmable Electronic Load (E-Load) machine model ZVL300-150-40L was used to vary the load on the H30 PEMFC.

\subsubsection{Experimental Procedure - 1}

a) Connect electric wire output of fuel cell to electrode of programmable electronic load machine.

b) Connect hydrogen supply to pressure regulator.

c) Setup the hydrogen supply to constant flow rate.

d) Record all the data obtain.

e) Plot the V vs I and P vs I graph.

f) Adjusting voltage by entering the value on the user panel button. 


\subsubsection{Result}

\section{$\mathrm{P}=\mathrm{VI}$}

The power, $\mathrm{P}$ in the above equation is a function of time and is called the instantaneous power. Thus the power absorbed or supplied by an element is the product of the voltage across the element and the current flow through it. If the power has a + sign, power is being delivered to be absorbed by the element.

Ohm's law states that the voltage $\mathrm{V}$ across a resistor to be the resistance, $\mathrm{R}$. (the resistance is a material property which can change if the internal or external conditions of the element are altered, e.g., if there are changes in the temperature). Thus, V = IR

For the first experiment, the current was set as a variable. The current was changed from the $1 \mathrm{~A}$ to $1.9 \mathrm{~A}$. From the result, we got the high power as $13.448 \mathrm{~W}$. For the second experiment, voltage was set as variable. The voltage was changed from $9.4 \mathrm{~V}$ to $7.5 \mathrm{~V}$. This PEMFC can supply until $9.4 \mathrm{~V}$, even though the theoretical value is $8.4 \mathrm{~V}$. The graph voltage versus current shows the voltage drops according to the current increase (Fig. 3). This current shows the load applied to the PEMFC. The capability of the PEMFC will drop if the load applied to it is increased (Fig. 4).

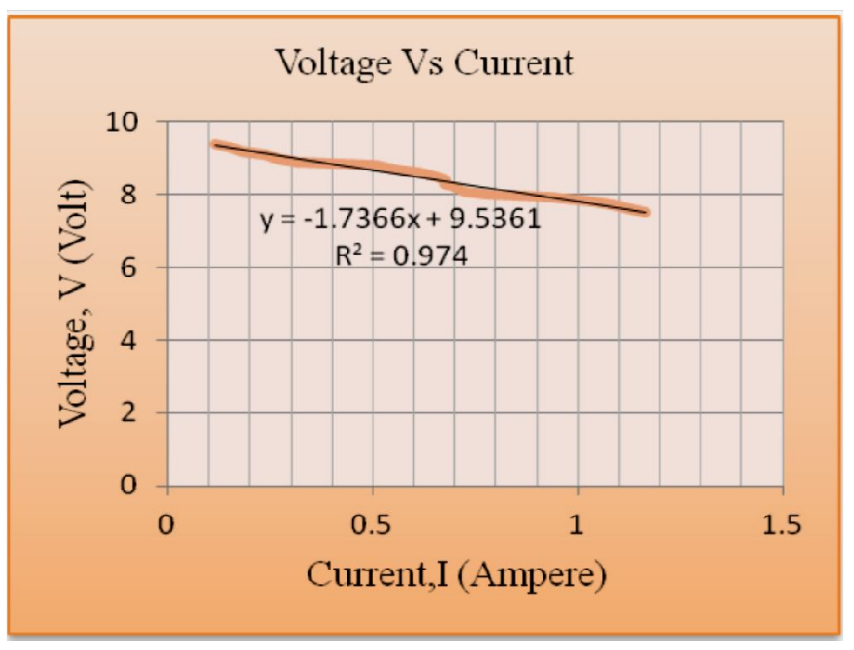

Fig. 3: Voltage vs current plot.

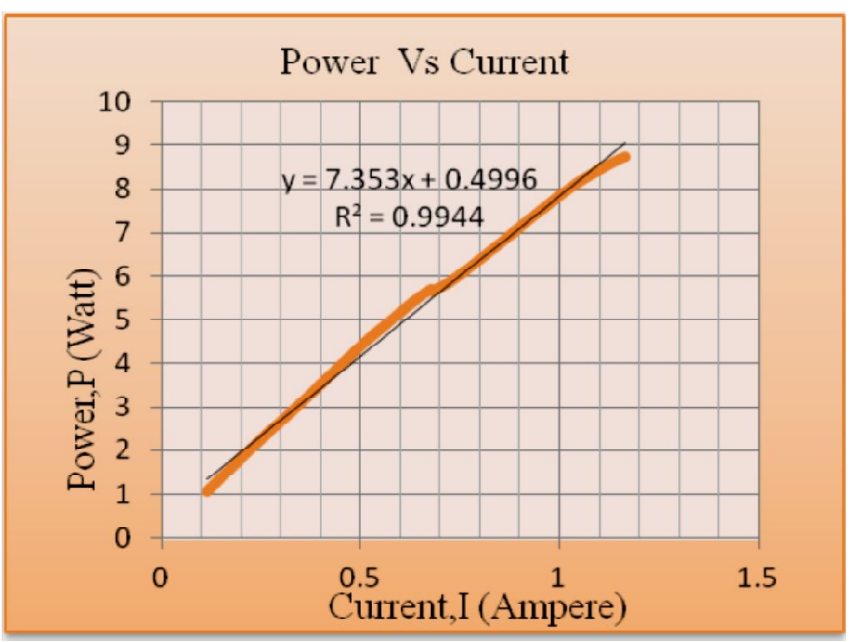

Fig. 4: Power vs current plot. 


\subsubsection{Experimental Procedure - 2}

i) Connect the flowmeter to the hydrogen supply system.

ii) The output of flowmeter tube is connected to the fuel cell.

iii) Once fuel cell is running, collect the reading shown on the flowmeter.

iv) Take the reading every $1 \mathrm{~min}$.

v) Compare the result with the supplier specification.

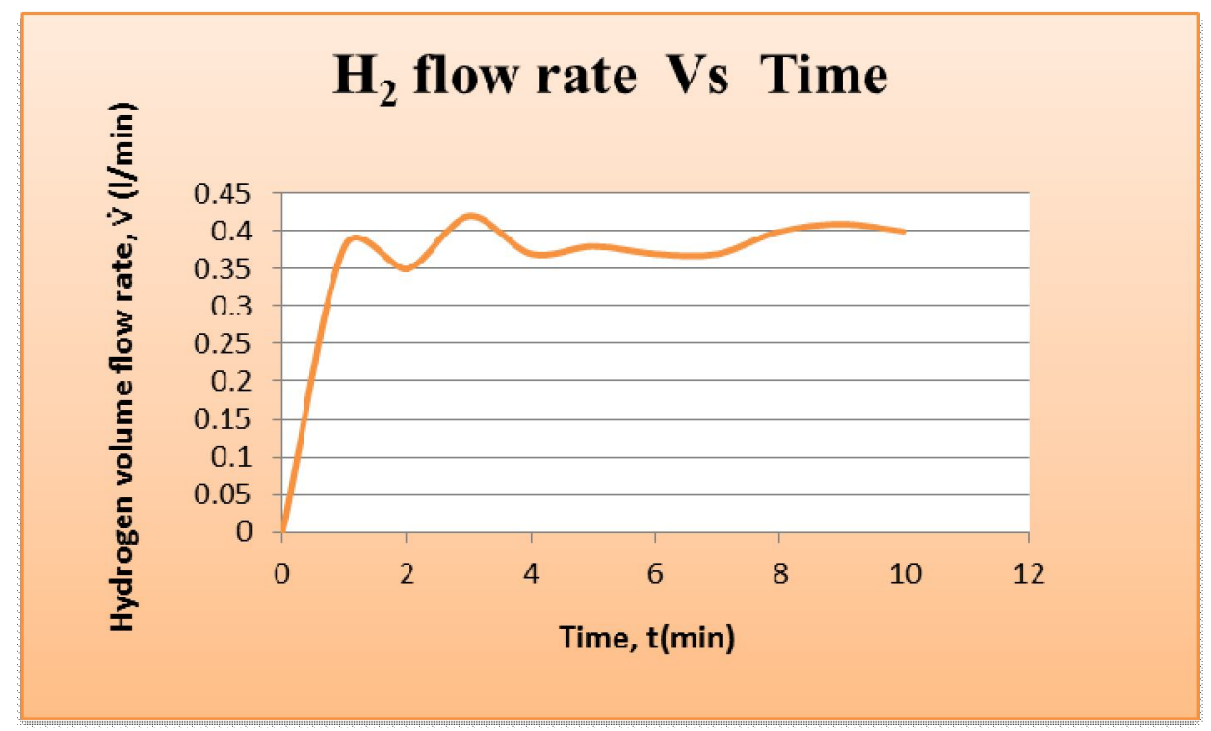

Fig. 5: $\mathrm{H}_{2}$ flow rate vs time plot.

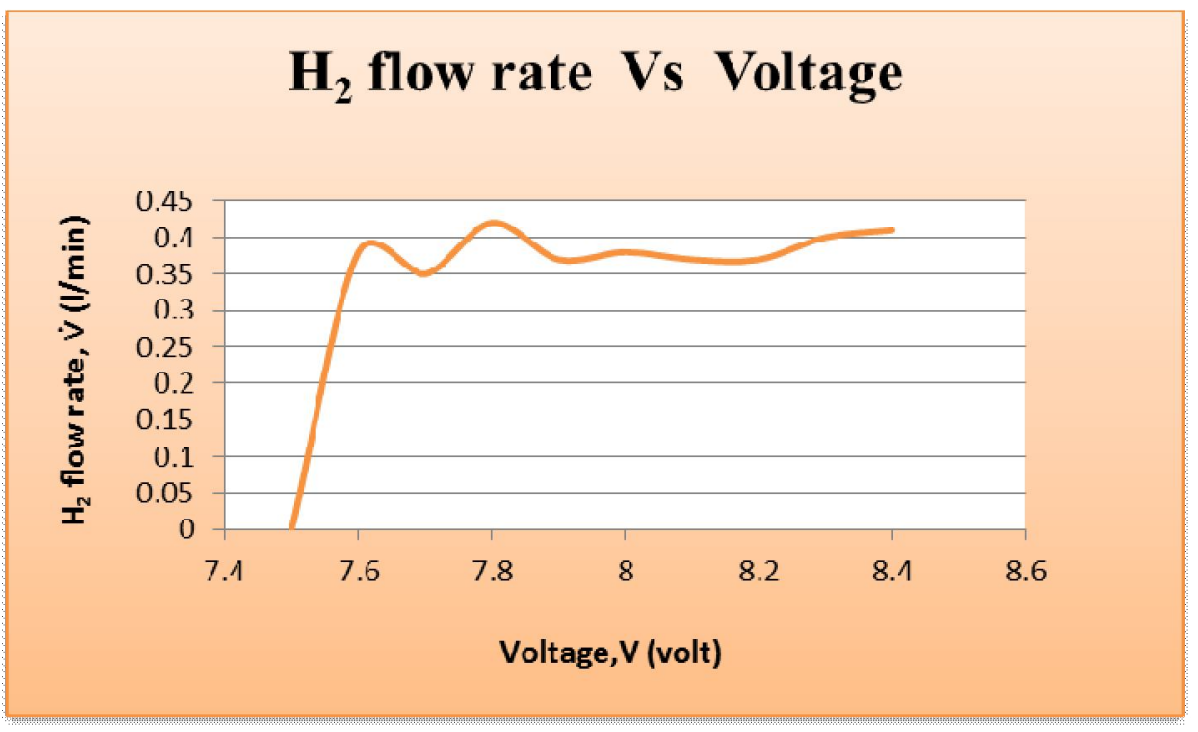

Fig. 6: $\mathrm{H}_{2}$ flow rate vs voltage plot.

Figures 5 and 6 show that the flow rate of hydrogen does not change rapidly with the variation of voltage and time. 


\section{CONCLUSION}

PEMFC powered vehicles could play a central role in future transportation systems. They produce only electricity, water and heat at the point of use. There has been great interest in hydrogen as a primary "energy carrier" displacing petroleum-based fuels.

The present work shows the development of a prototype car powered by PEM fuel cell. It shows the possibility to replace the conventional internal combustion engine with fuel cell. It is now a reality to think for fuel cell car though the present day technology it is little costlier. The performance of the fuel cell car prototype is interesting, eventhough it is not producing high performance but it produces zero emissions. Futher research needs to be carried out to improve its performance.

It is hoped that fuel cell vehicle will become the conventional vehicle in the future. It is because of their emissions that will cause no harm to the environment. The government should play an important role in the process of developing this zero emission vehicle.

\section{REFERENCES}

[1] Environmental Protection Agency (1991) Office of air quality planning and standards. national air pollutant emissions estimates. EPA-450/-4-91-004, Research Triangle Park, North Carolina, USA.

[2] DeLuchi MA. (1991) Emissions of greenhouse gases from the use of transportation fuels and electricity. ANL/ESD/TM-22, Argonne National Laboratory, Argonne, Illinois, USA.

[3] Buchner H, Povet R. (1982) The Daimler-Benz hydride vehicle project. Int J Hydrogen Energy, 7:259-266.

[4] Stewart WF. (1984) Operating experience with a liquid hydrogen fueled Buick and refueling system. Int J Hydrogen Energy, 9:525-538.

[5] Grunenfelder NF, Schucan T. (1989) Seasonal storage of hydrogen in liquid organic hydrides: Description of the second prototype vehicle. Int J Hydrogen Energy, 14:579-586.

[6] Barbir F. (2005) PEM fuel cells: Theory and practice. Elsevier Academic Press, New York.

[7] Devrim Y, Erkan S, Bac N, Eroglu I. (2009) Preparation and characterization of sulfonated polysulfone/titanium dioxide composite membranes for proton exchange membrane fuel cells. Int J Hydrogen Energy, 34:3467-3475.

[8] Zhang J, Xie Z, Zhang J, Tang Y, Song C, Navessin T, et al. (2006) High temperature PEM fuel cells. J Power Sources, 160:872-891.

[9] Yang C, Costamagna P, Srinivasan SJ, Benziger J, Bocarsly AB. (2001) Approaches and technical challenges to high temperature operation of proton exchange membrane fuel cells. J Power Sources, 103:1-9.

[10] Li X. (2006) Principal of fuel cells. Taylor \& Francis Group, New York.

[11] Spiegel C. (2007) Designing and building fuel cells. McGraw-Hill, New York.

[12] Mohiuddin AKM, Chemani MF, Zakaria MB. (2014) Design and investigation of a fuel Cell car prototype. Int. J. Engineering Systems Modelling and Simulation, 9 (3/4):321-333.

[13] Thring RH. (2004) Fuel cells for automotive applications. Bury St Edmunds, Professional Engineering Pub. UK. 